\title{
Flow routing with Semi-distributed hydrological model HEC- HMS in case of Narayani River Basin
}

\author{
Narayan Prasad Gautam \\ Pashchimanchal Campus, Institute of Engineering, Tribhuvan University, Pokhara, Nepal \\ Corresponding Email: gautamnp43@yahoo.com
}

\begin{abstract}
Routing is the modeling process to determine the outflow at an outlet from given inflow at upstream of the channel. A hydrological simulation model use mathematical equations that establish relationships between inputs and outputs of water system and simulates the catchment response to the rainfall input. Several hydrological models have been developed to assist in understanding of hydrologic system and water resources management. A model, once calibrated and verified on catchments, provides a multi-purpose tool for further analysis. Semi-Distributed models in hydrology are usually physically based in that they are defined in terms of theoretically acceptable continuum equations. They do, however, involve some degree of lumping since analytical solutions to the equations cannot be found, and so approximate numerical solutions, based on a finite difference or finite element discretization of the space and time dimensions, are implemented.

Many rivers in Nepal are either ungauged or poorly gauged due to extreme complex terrains, monsoon climate and lack of technical and financial supports. In this context the role of hydrological models are extremely useful. In practical applications, hydrological routing methods are relatively simple to implement reasonably accurate.

In this study, Gandaki river basin was taken for the study area. Kinematic wave method was used for overland routing and Muskingum cunge method was applied for channel routing to describe the discharge on Narayani river and peak flow attenuation and dispersion observed in the direct runoff hydrograph. Channel cross section parameters are extracted using HEC- GeoRAS extension tool of GIS. From this study result, Annual runoff, Peak flow and time of peak at the outlet are similar to the observed flow in calibration and verification period using trapezoidal channel. Hence Hydrological modeling is a powerful technique in the planning and development of integrated approach for management of water resources
\end{abstract}

Keywords: routing, hydrograph, hydrological modeling, semi distributed model, HEC-HMS, DEM, Muskingum cunge

\section{Introduction}

Flow Routing is the procedure to determine the out flow hydrograph at a downstream point of a river from given inflow hydrograph at an upstream point there of basin. The shape of the outflow hydrograph depends upon the channel geometry, bed slope. Length of the channel reach, downstream control, initial channel flow and the upstream inflow hydrograph. Flow routing is a mathematical method for prediction the changing magnitude and celerity of a flood wave as it propagates down rivers or reservoir (Fread 1981 and Linsley et. Al 1982) Generally flow routing methods are categorized into two board but somewhat related applications, namely reservoir routing and open channel routing (Lawyer 1964) these methods are frequently used to estimate inflow or outflow hydrograph and peak flow rates in reservoir, river reaches, tanks swamps and lakes (NRCS, 1972). 
A flow routing model is used to estimate the out flow hydrograph by routing of flow event from an upstream flow gauging station to a downstream station. Flood routing procedure may be classified as either hydrological or hydraulics (Chaudhari et. Al 2002). The selection of a routing model is also influenced by the required accuracy, the type and availability of data, the available computational facilities, computational cost, the extent of flood wave information desired and familiarity of the users with the given model (NERC, 1975; Fread 1981). In practical applications hydrological routing methods are relatively simple to implement reasonably accurate (Haktanir and Ozmen 1997). A watershed is usually a complex and heterogeneous system. Its characteristics vary in space. Hydrologic process varies both in space and time. For special variability of governing hydrologic factors is to divide the watershed into nearly homogenous sub basins.

Stream flow may be significantly affected by the difference in soil, vegetation, land use or topography of the watershed and geometry of channel [6]. The flow of water through soil and stream channels of watershed is a distributed process because the flow rate, velocity and depth vary in space throughout the watershed. Estimate of the flow rate or water level at important location in the channel system can be obtained using a distributed flow routing model. This type of model is based on partial differential equations (the Saint Venant equations for one dimensional flow) that allow the flow rate and water level to be computed as functional space and time. Hydrological modeling in a watershed became complex, tedious and sophisticated by using natural channel due to lack of required information about irregularity of channel reaches. Depending upon the drainage pattern, geometry of the channel and existence of dams, reservoirs, bridge etc. within the basin, the DRH of each sub basin is to be routed during its journey to the watershed outlet to compute out flow hydrograph on the outlet reach. The effect of watershed subdivision (or discretization) on the prediction accuracy of hydrological models on 12 watersheds was evaluated by Hromadka et al. (1988). They used a simple model based on the unit hydrograph method. Since most of rainfall runoff models achieve their greatest accuracy for smaller to medium sized watershed. It is beneficial to divide the main watershed into subwatershed to increase the accuracy of model results.

\section{Tools use for routing}

\section{$2.1 \quad$ HEC-HMS model}

Hydrological modeling system (HMS) is software system designed by US Army Crops of Engineer (USACE) used to simulate the precipitation, runoff simulation that supersedes the HEC program HEC-1. The initial program release in 1998 contains most of the event based simulation capabilities. HMS requires three input components:

1. Basin model, which describes the different elements of the hydrologic system i.e. subdivision, reaches, junction, sources, sinks reservoir and diversion.

2. Metrological model, which describes the modeling of precipitation process as well as the evaporation process both in spatially and temporally.

3. Control specification, which defines the time window for the simulation.

HMS has been applied widely in USA and many countries for solving the widest possible range of problems, which includes large river basin water supply, flood hydrology, and small urban or natural watershed runoff. So, HEC-HMS is considered the standard model in the United States 
for hydrologic design problems such as the design of drainage systems, quantifying the effect of land-use change on flooding, etc (Singh 2002). A GIS companion product called the Geospatial Hydrologic Modeling Extension (HEC-GeoHMS) has been developed to aid in the creation of basin models and meteorological models for use with this software.

Hydrologic models HEC-HMS and hydrodynamic model HEC-RAS are used to simulate flood in river. The HEC-RAS model is applied to route flood from two stations. HEC-RAS model are used to prepare inundation map to determine flooded area at floodplain by HEC-GEORAS which are an extension of Arc view-GIS. In addition, a database management program is created by Visual Basic and Microsoft Access combining with GIS application to store, to display, to query and to assist flood forecasting. HEC-HMS 3.1 is a well know semi distributed rainfall runoff model which give the result as required by manipulating the data. The supporting tools for model are Geographic Information system (GIS) with extension HEC-GEORAS 3.1 and HECGEOHMS 3.1

\section{$2.2 \quad$ HEC-HMS 3.2}

HEC-HMS 3.2 (Hydrologic Modeling system) is designed by US army of Engineers (USACE) to simulate the precipitation-runoff processes of dendrite watershed systems. The hydrographs achieved by model can be used for studies of water availability, flow forecasting, reservoir spillway design, floodplain regulation, urban drainage and systems operation with attached other software Arc View GIS 3.2

ArcView is software, designed by Environmental System Research Institute (ESRI, 1995) for viewing and analyzing geospatial information. It is equipped with excellent graphical user interface (GUI), which enables visualization, exploring and analysis of spatial data. It has also the facility to display tables, charts, layouts associated with the shape files. The processing, modeling, visualization and interpretation of grid based raster data can be performed using the spatial analysis extension. GEOHMS has been the most powerful extension tool to perform river generation and basin delineation. Similarly, the three dimensional surface creation, visualization and analysis can be done using 3D analyst extension.

\subsection{HEC-GeoRAS}

HEC-GeoRAS is an ArcView GIS extension specifically designed to process geospatial data for use with the Hydrologic Engineering Center's River Analysis System (HEC-RAS). The extension allows users to create a HEC-RAS import file containing geometric attribute data from an existing Digital Terrain Model (DTM) and complementary data sets. To create the import file, an existing Digital Terrain Model (DTM) of the river system in the TIN (Triangulated Irregular Network) format is required. The TIN is a surface representation derived from interconnected and non overlapping triangles. The irregularly spaced sample points from the vertices of the triangle. Each point has the $\mathrm{x}, \mathrm{y}$ coordinate and a surface or $\mathrm{Z}$-value (elevation value). This TIN model can be created either from the contour or DEM.

The channel shape, principle dimension of channel cross section and channel side slope is extracted for implementing the kinematic model in HEC-HMS In order to access such physical characteristics of the natural channel the extension software of ArcView GIS developed by USACE, HEC-GEORAS can be used. 


\subsection{HEC -GEOHMS 1.1}

The geospatial Hydrologic Modeling (HEC -GEOHMS ) extension is a software using with GIS for terrain processing and to calculate the physical characteristics of the sub basins. It is a tool to perform stream and sub basin delineation and calculates many physical character.

\subsection{Digital Elevation Model (DEM)}

The DEM is the important input to describe the topography of the watershed on the base of semi distributed model. The DEM used in this study is of 100 meters resolution i.e. $100 * 100 \mathrm{~m}$ grid size. Stream map and stream network are also derived by imposing digitized stream network on the DEM.

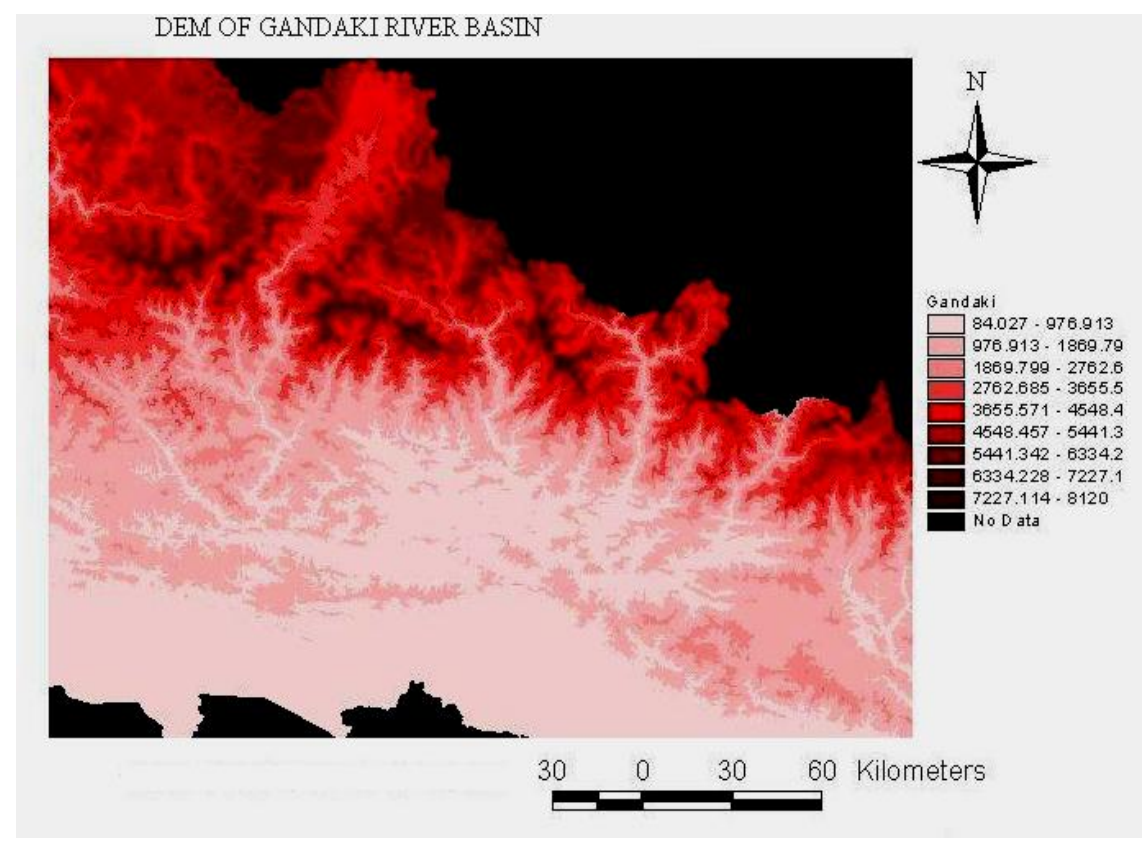

Figure 1: DEM image of Gandaki River Basin

\section{Study Area (Narayani river basin)}

Narayani river basin of Nepal is situated in the Western and Central development Region between latitudes $27.63 \mathrm{~N}$ to $29.87 \mathrm{~N}$ and $82.83 \mathrm{E}$ to $86.79 \mathrm{E}$. It has the elevation from $73 \mathrm{~m}$ to about $7163 \mathrm{~m}$ which extends from the Himalayan range to the Nepal to India border.

It covers 19 districts of Nepal and some area of China also. The catchments area of the basin is 30162 sq Km in Nepal and 10590 sq. Km in China.It has been located manang, Mustang, Gorkha, Lamjung, Kaski, Baglung, Myagdi, Parbat, Tanahu, Syangja, Rasuwa, Dhading, Nuwakot, Chitawan, Palpa, Makawanpur, Arghakhanchi, Nawalparasi and Gulmi districts. The Major river in this basin are Kali Gandaki river originated from Mustang district ,Trisuli, Marsyandi, Madi khola, Modi khola, Seti river and Budhi Gandaki river. 


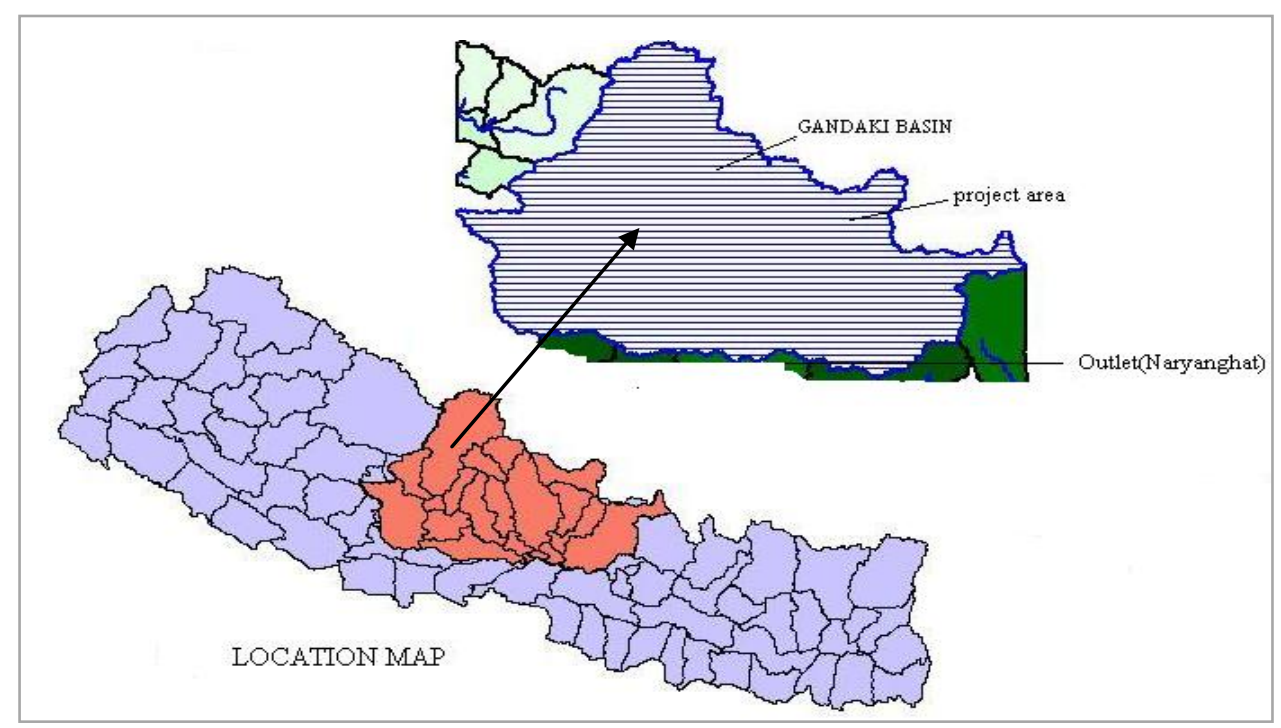

Figure 2: Location Map

\section{Methodology of the modeling}

The semi-distributed model to simulate the river flow on watershed was used to simulate basin. The study deals with pre processing and spatial analysis of the Digital elevation model (DEM) for the automated delineation of sub basins and river. GIS extension tools were used for the extraction of physical characteristics of sub basin and rivers. Required other model parameters such as daily precipitation, evapotranspiration are collected from DHM and analyze by thiessen polygon method. Hydraulic conductivity, suction head, initial moisture deficit and roughness coefficient are extracted on the basis of soil and land use map of the study area and these models parameters are used in HEC-HMS model simulation.

Hydraulic parameters are routed by using kinematic wave method for overland and Muskigum cunge method for channel routing. Simulated flow is compared with the observed flow at the outlet of the basin and analyzes the performance of the result to achieve the objective of the study. For routing process, collection of the relevant metrological, hydrological and topographical datas is essential for the study. Metrological and hydrological data such as precipitation and discharge respectively are acquired from the Department of hydrology and meteorology (DHM) whereas topographical data of $100 \mathrm{~m} \times 100 \mathrm{~m}$ resolution Digital map (DEM) is available easily.

\subsection{Flow diagram of the methodology:}

A conceptual framework serves to describe the overall study steps. The main data types are required as input includes rainfall, DEM (digital elevation model) soil, land use and metrological for model. After having dates, HEC-HMS model are operated. The main output from model is discharge at the outlet of the catchment. Finally, the output is compared with the real discharge at selected gauging of the basin. 


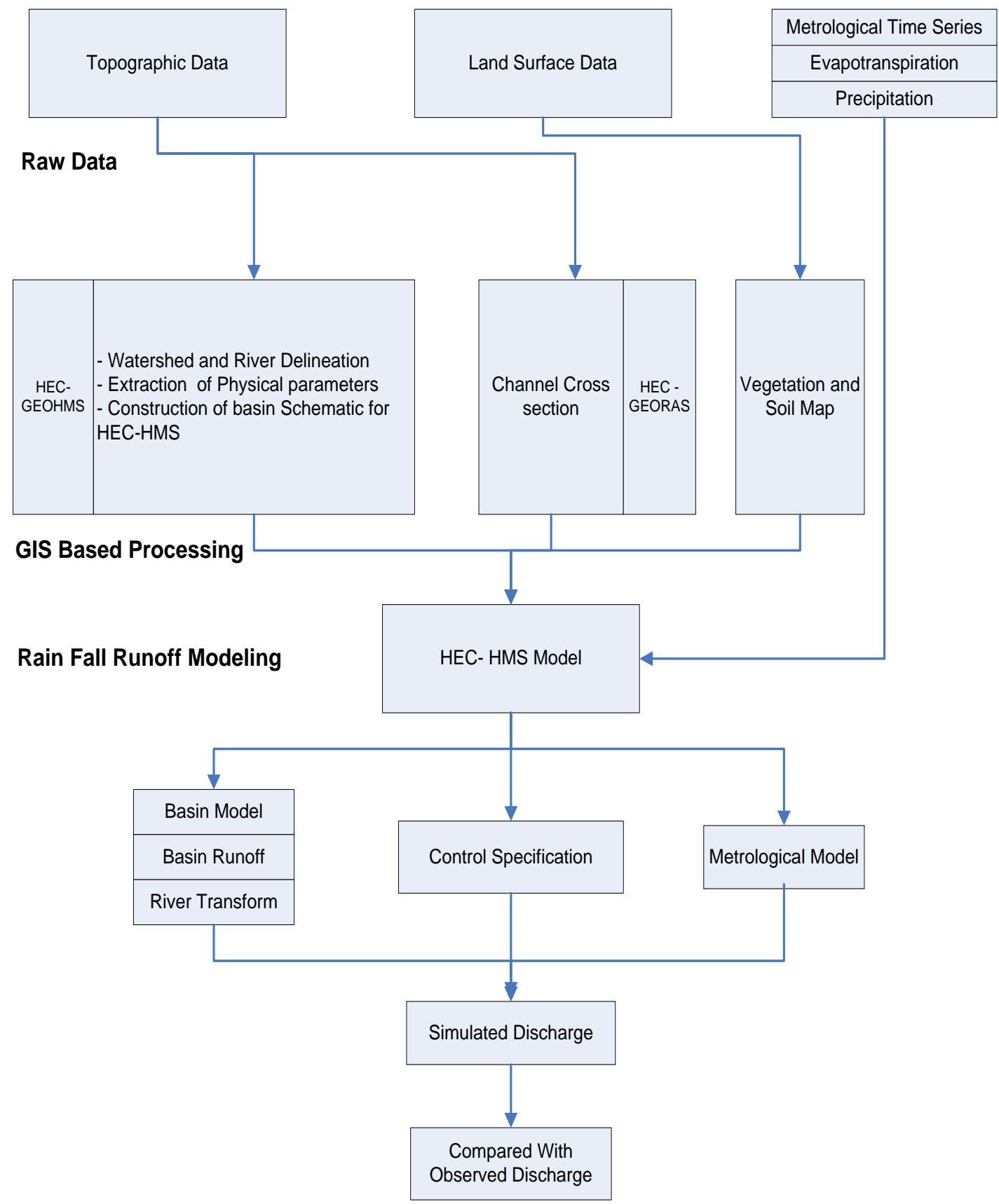

Figure 3: Flow diagrams for methodology 


\section{Result and conclusion}

The temporal variation of the flow by using trapezoidal channel sections was analyzed and examined the result of trapezoidal channel geometries at the outlet of the watershed at Narayanghat by considering the model's response of three-year separate precipitation. Sub basins and rivers were delineated then extracted terrain characteristics with the aid of digital elevation model. The basin was divided into 23 sub basins on the basis of river network, land use and soil type. The hydrologic parameters were obtained by comparing with observed flow. Runoff from each of the sub basin is estimated and routed using kinematic wave method and rivers and channels are routed using Muskingum cunge method to calculate total flow at the outlet of basin is presented in this section.

\subsection{Model calibration}

The model is calibrated using 2004 and 2005 daily rainfall runoff data. Manual and automatic calibration techniques are applied to estimate values of parameters.

The whole study area is divided into twenty- three sub basin. The sub basins are assumed to be homogenous and the model parameters are assigned according to the type of soil and land use pattern within sub-basin. The optimal values of the model parameters are obtained using the criterion of maximizing the efficiency by comparing the observed and simulated flows. The accuracy of the model is verified by qualitative and quantitative analysis.

\subsubsection{Comparison of simulated and observed hydrograph}

The simulated and observed hydrograph and scatter plot using trapezoidal channel at calibration period 2004 to 2005 for routing is shown in fig. It is indicated that the trend and shape of the simulated and observed hydrograph is nearly similar. This result show that base flow is matched with the observed flow but Peak discharge is slightly greater than observed peak. The total volume is under estimated and peak flow is overestimated than observed flow. The Nash efficiency and volume of deviation for trapezoidal section is $90.49 \%$ and $7.13 \%$ respectively. The coefficient of determination for calibration period 2004 and 2005 is 0.906 for trapezoidal channel section.

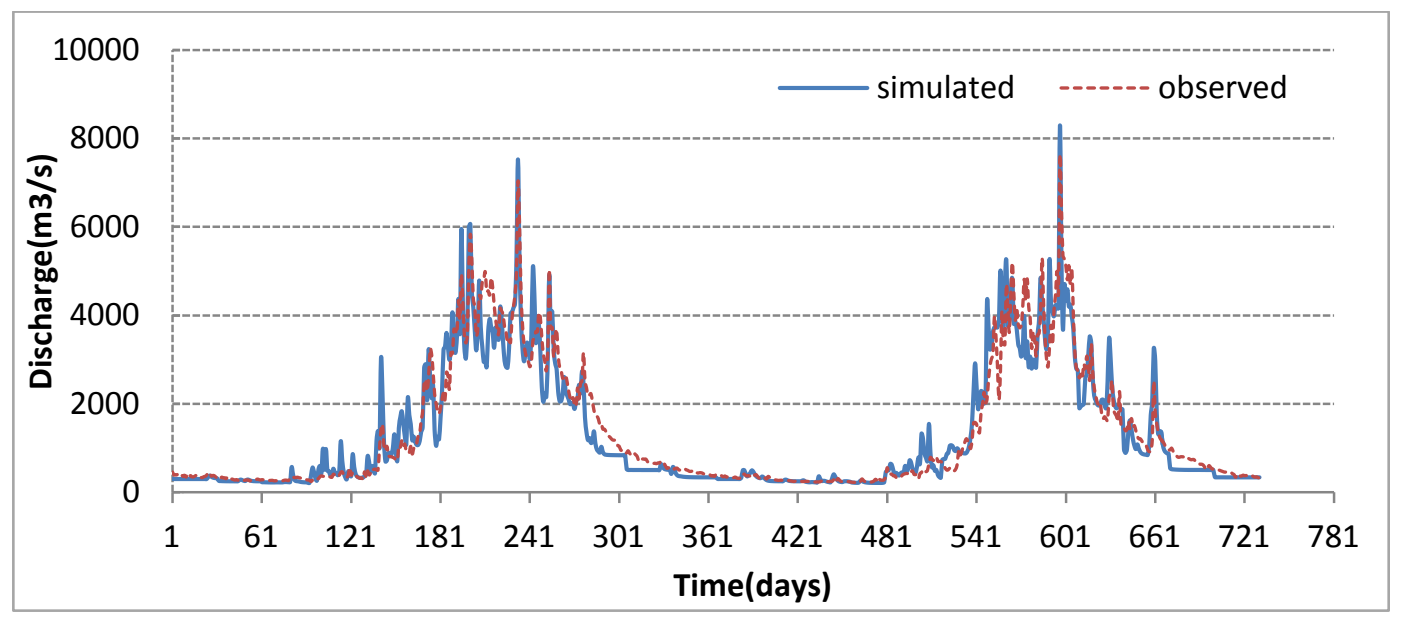

Figure 4: Comparison of simulated with observed hydrograph for validation period $2004 \& 2005$ 


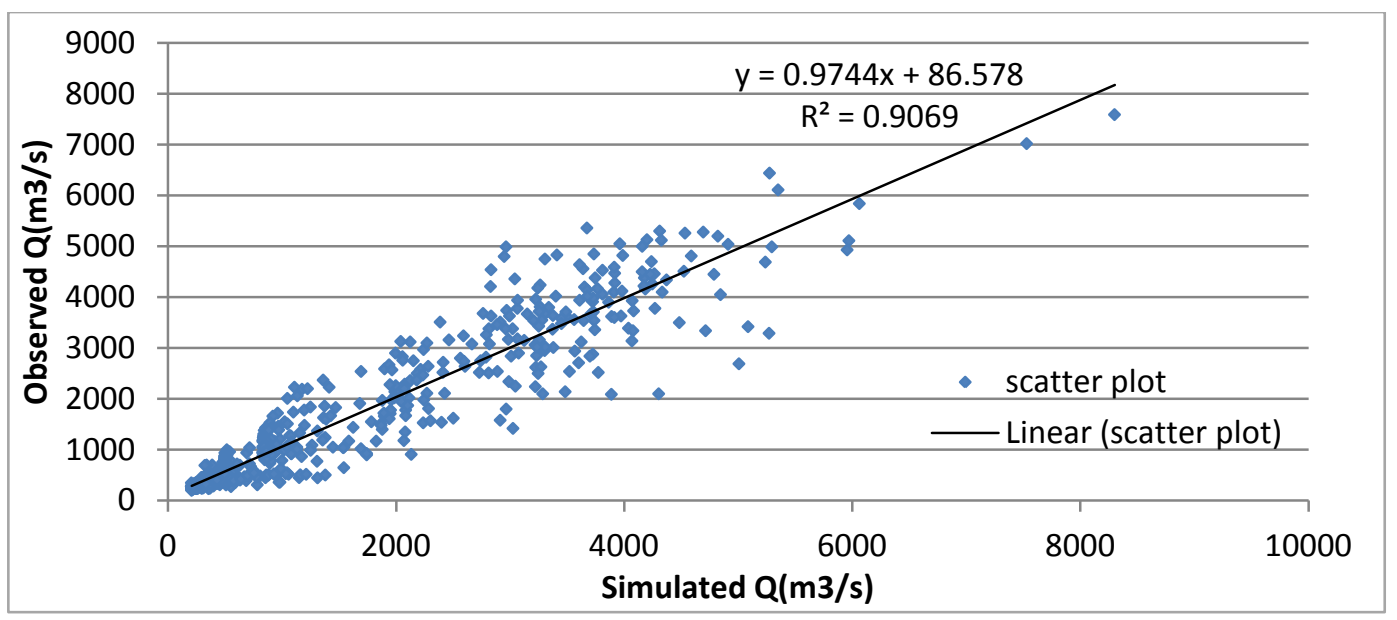

Figure 5: Scatter plot for calibration period 2004\&2005

\subsection{Model validation}

The model is run for one year's daily rainfall runoff data. The runoff is simulated using 2006 daily rainfall-runoff data in model validation. The calibrated model parameters are applied in model validation.

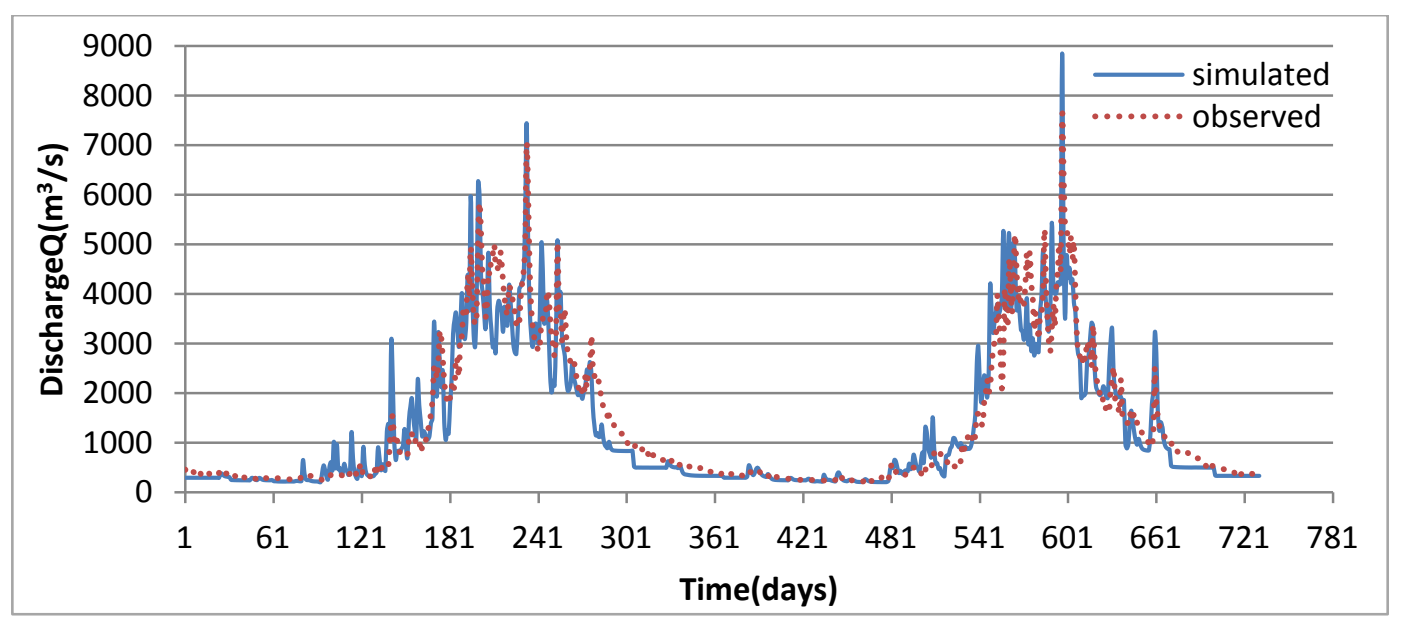

Figure 6: Comparison of simulated and observed hydrograph

The simulated and observed hydrograph and scatter plot using trapezoidal channel at validation period 2006 for routing is presented in the graphical form in fig.5.2.2. It is indicated that the trend and shape of the simulated is nearly matched with observed hydrograph. This result show that Peak flow is also matched with observed flow. The time of peak of the simulated and observed flow at $28^{\text {th }}$ August 2006. The total volume is over estimated and peak flow is under estimated than observed flow. The Nash efficiency and degree of determination (R-square value) is $88.76 \%$ and 0.89 respectively. The Nash-Sutcliffe (1970) efficiency at validation period is slightly lower than calibration period. 


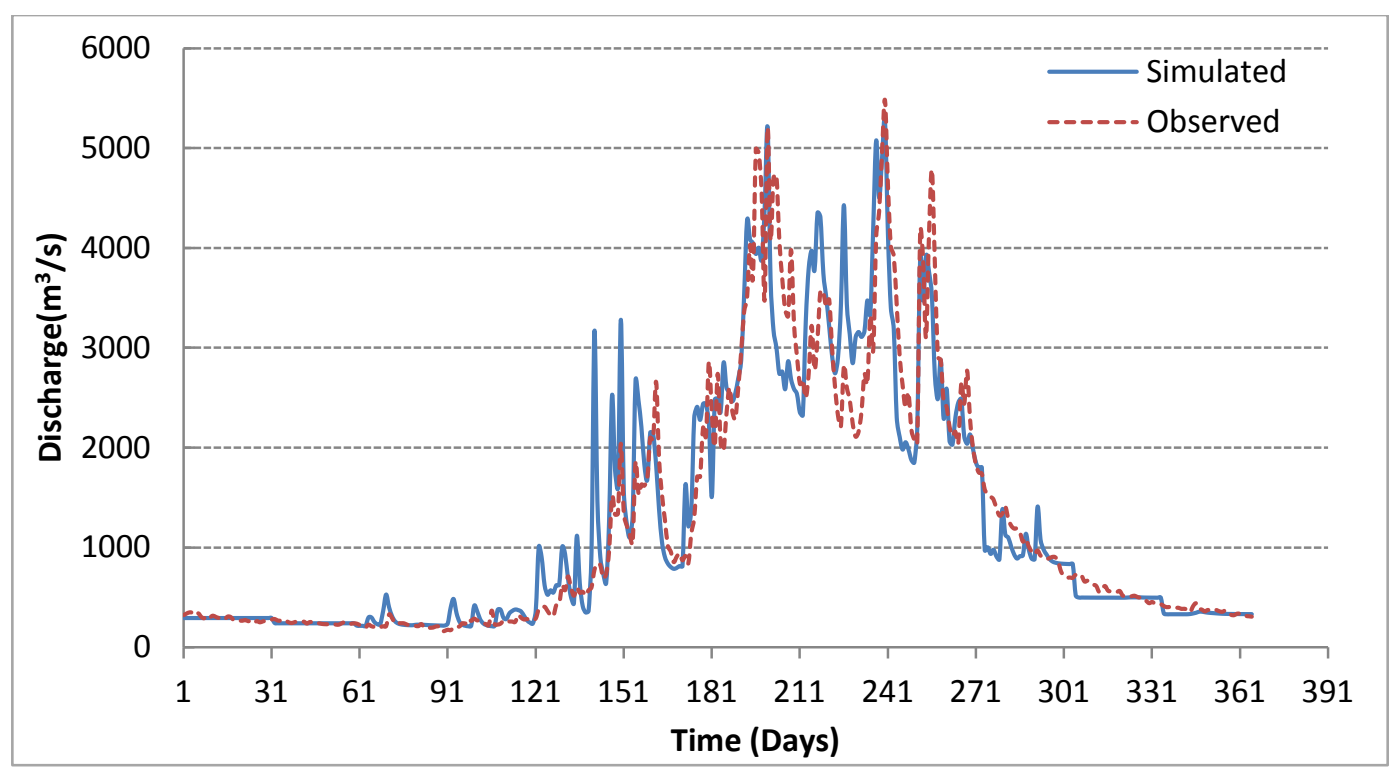

Figure 7: Comparison of simulated and observed hydrograph for validation period 2006

\section{Analysis of Modeling}

\subsection{Performance Analysis on Volume Deviation}

The simulated annual stream flow volume that occurred at the outlet of the basin in response to the channel geometries during calibration and validation period. The volume deviation using trapezoidal and triangular section obtained almost similar but in rectangular channel the volume deviation is higher than other section

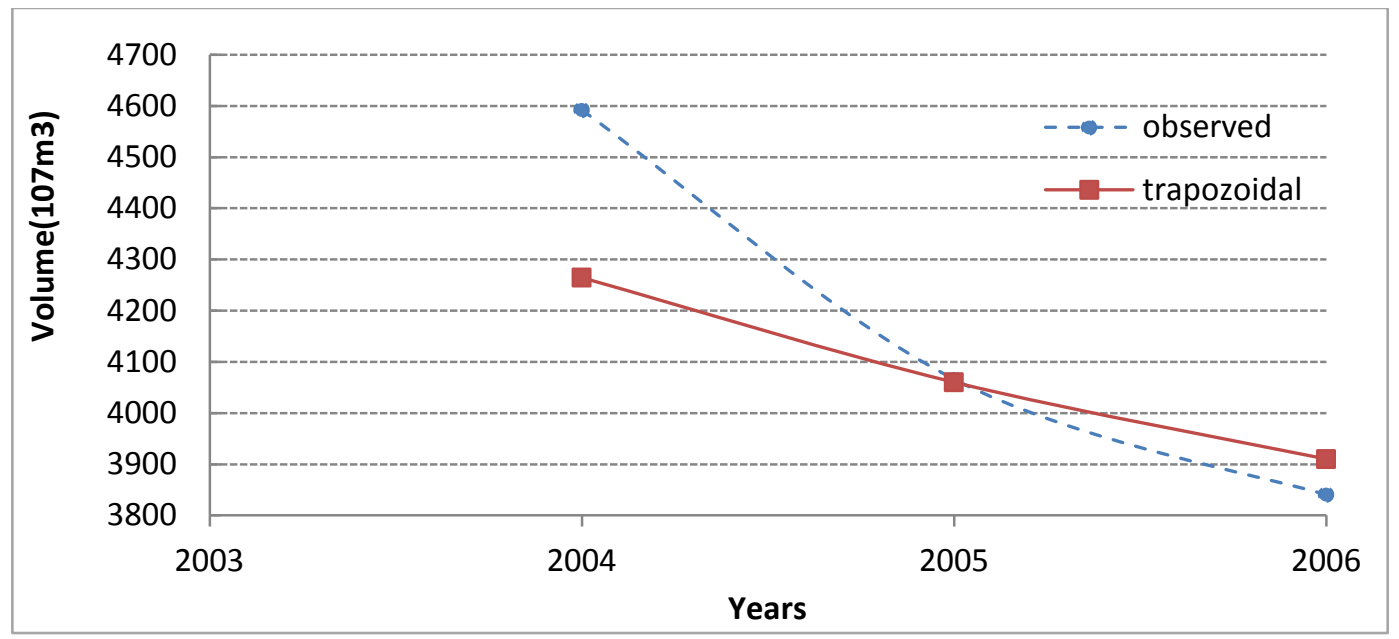

Figure 8: Annual stream flow volume at the outlet 
Table 1: Annual stream flow volume at the outlet

\begin{tabular}{|c|c|c|c|c|c|c|}
\hline \multirow{3}{*}{$\begin{array}{c}\text { Channel } \\
\text { section }\end{array}$} & $\begin{array}{c}\text { Observed } \\
\text { volume } \\
\left(10^{7} \mathrm{~m}^{3}\right)\end{array}$ & $\begin{array}{c}\text { simulated } \\
\text { volume } \\
\left(10^{7} \mathrm{~m} 3\right)\end{array}$ & $\begin{array}{c}\text { Observed } \\
\text { volume } \\
\left(10^{7} \mathrm{~m}^{3}\right)\end{array}$ & $\begin{array}{c}\text { simulated } \\
\text { volume } \\
\left(10^{7} \mathrm{~m} 3\right)\end{array}$ & $\begin{array}{c}\text { Observed } \\
\text { volume } \\
\left(10^{7} \mathrm{~m}^{3}\right)\end{array}$ & $\begin{array}{c}\text { simulated } \\
\text { volume } \\
\left(10^{7} \mathrm{~m} 3\right)\end{array}$ \\
\hline Trapezoidal & 4591.8 & 4264.458 & 4066.3 & 4060.03 & 3840.46 & 3909.9 \\
\hline
\end{tabular}

\subsection{Performance analysis on annual mean flow}

The simulated annual mean stream flow was occurred at the outlet of the basin in response to the channel geometries during calibration and validation period. The annual mean flow was obtained almost similar.

Table 2: Annual mean flows at the outlet

\begin{tabular}{|c|c|c|c|c|c|c|}
\hline \multirow{2}{*}{$\begin{array}{c}\text { Channel } \\
\text { section }\end{array}$} & $\begin{array}{c}\text { Observed } \\
\text { Peak flow } \\
\left(\mathrm{m}^{3} / \mathrm{s}\right)\end{array}$ & $\begin{array}{c}\text { Simulated } \\
\text { Peak flow } \\
\left(\mathrm{m}^{3} / \mathrm{s}\right)\end{array}$ & $\begin{array}{c}\text { Observed } \\
\text { Peak flow } \\
\left(\mathrm{m}^{3} / \mathrm{s}\right)\end{array}$ & $\begin{array}{c}\text { Simulated } \\
\text { Peak flow } \\
\left(\mathrm{m}^{3} / \mathrm{s}\right)\end{array}$ & $\begin{array}{c}\text { Observed } \\
\text { Peak flow } \\
\left(\mathrm{m}^{3} / \mathrm{s}\right)\end{array}$ & $\begin{array}{c}\text { Simulated } \\
\text { Peak flow } \\
\left(\mathrm{m}^{3} / \mathrm{s}\right)\end{array}$ \\
\hline Trapezoidal & 7020 & 7531.3 & 7590 & 8302.1 & 5480 & 5277.8 \\
\hline
\end{tabular}

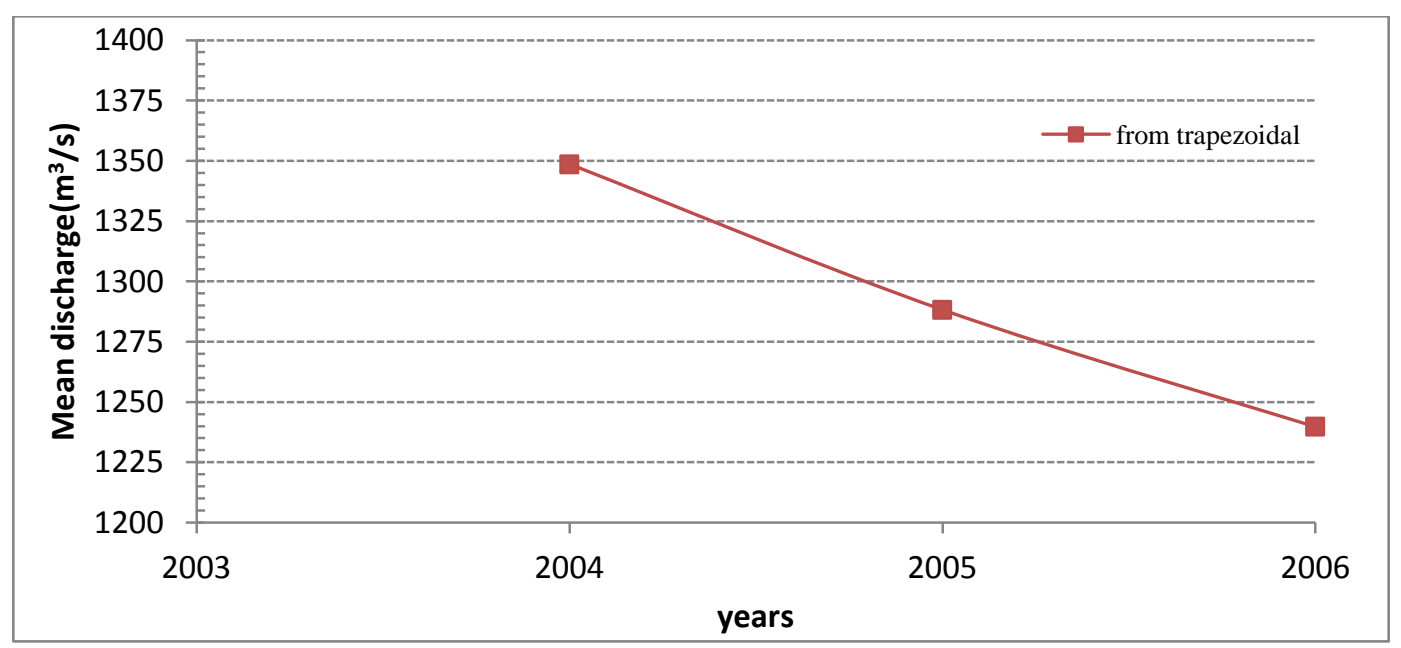

Figure 9: Annual mean stream flow at the outlet

\subsection{Performance analysis on peak flow}

The simulated peak stream flow was occurred at the outlet of the basin in response to the channel geometries during calibration and validation period. The time of peak using trapezoidal channel exactly same to the observed time of peak in calibration and validation period. 
Table 3: Peak flow at the outlet

\begin{tabular}{|c|c|c|c|c|c|c|}
\hline \multirow{2}{*}{$\begin{array}{c}\text { Channel } \\
\text { section }\end{array}$} & $\begin{array}{c}\text { Observed } \\
\text { Peak flow } \\
\left(\mathrm{m}^{3} / \mathrm{s}\right)\end{array}$ & $\begin{array}{c}\text { Simulated } \\
\text { Peak flow } \\
\left(\mathrm{m}^{3} / \mathrm{s}\right)\end{array}$ & $\begin{array}{c}\text { Observed } \\
\text { Peak flow } \\
\left(\mathrm{m}^{3} / \mathrm{s}\right)\end{array}$ & $\begin{array}{c}\text { Simulated } \\
\text { Peak flow } \\
\left(\mathrm{m}^{3} / \mathrm{s}\right)\end{array}$ & $\begin{array}{c}\text { Observed } \\
\text { Peak flow } \\
\left(\mathrm{m}^{3} / \mathrm{s}\right)\end{array}$ & $\begin{array}{c}\text { Simulated } \\
\text { Peak flow } \\
\left(\mathrm{m}^{3} / \mathrm{s}\right)\end{array}$ \\
\hline Trapezoidal & 7020 & 7531.3 & 7590 & 8302.1 & 5480 & 5277.8 \\
\hline
\end{tabular}

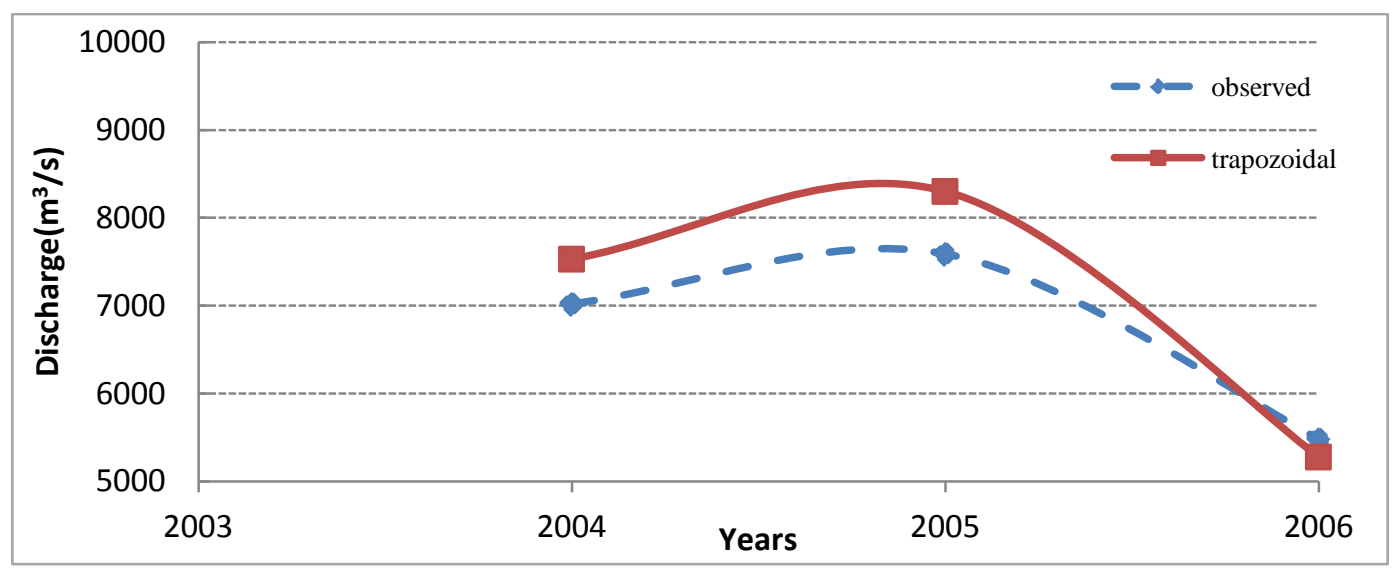

Figure 10: Peak flow at the outlet

Table 4: Time of Peak at the Outlet

\begin{tabular}{|c|c|c|c|c|c|c|}
\hline \multirow{2}{*}{$\begin{array}{c}\text { Channel } \\
\text { section }\end{array}$} & $\begin{array}{c}\text { Observed } \\
\text { peak time } \\
\text { in days }\end{array}$ & $\begin{array}{c}\text { simulated } \\
\text { peak time } \\
\text { in days }\end{array}$ & $\begin{array}{c}\text { Observed } \\
\text { peak time } \\
\text { in days }\end{array}$ & $\begin{array}{c}\text { simulated } \\
\text { peak time } \\
\text { in days }\end{array}$ & $\begin{array}{c}\text { Observed } \\
\text { peak time } \\
\text { in days }\end{array}$ & $\begin{array}{c}\text { simulated } \\
\text { peak time } \\
\text { in days }\end{array}$ \\
\hline Trapezoidal & 20 August & 20 August & 19 August & 19 August & 28 August & 28 August \\
\hline
\end{tabular}

\subsection{Performance analysis on efficiency}

The Nash -Sutcliffe (1970), efficiency of stream flow that occurred at the outlet of the basin in response to the channel geometry (trapezoidal section) during calibration and validation period shown in graph.

It is clear from simulated hydrographs that different channel section show different degree of agreement between molded and observed discharge. Explanations for the results obtained can be pointed out in the following bullets.

- The precipitation, the infiltration parameters and channel routing method and parameters cause the difference in Peak flow, peak timing, and total volume, annual mean flow of observed and simulated hydrographs.

- Basins with a greater diversity of basin characteristics, including topography, soils and land use will produce poorer results than homogenous basins. 
- Stream flow is affected by selection of channel geometry.

- Errors in peak flow due to inaccurate precipitation, inaccurate sub basin runoff parameters, incorrect timing of tributaries or the wrong amount of attenuation in channel routing.

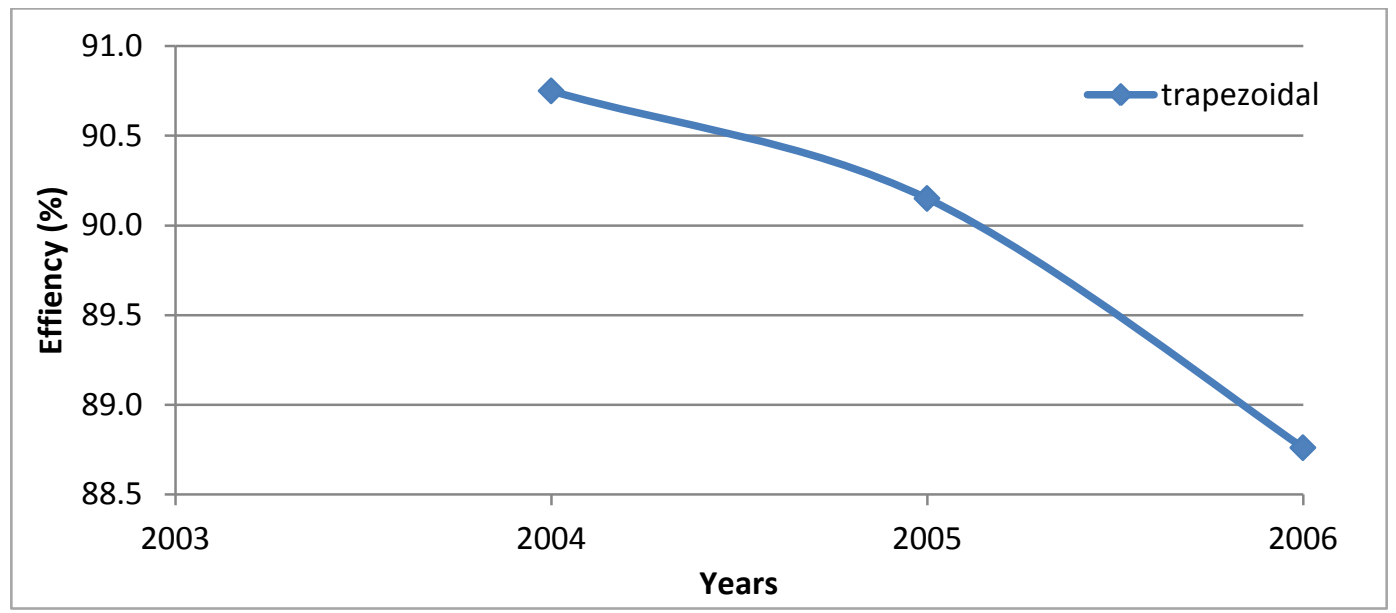

Figure 11: Efficiency of the modeling

\section{Conclusion and Recommendation}

\subsection{Conclusion}

The main objective of this study was to identify flow by simulated and observed at trapezoidal section in the computer-based rainfall runoff processes for Narayani river basin. The GIS based semi-distributed model named HEC-HMS was used for this study. The response of model in simulating rainfall runoff was analyzed for the basin using DEM, Evapotranspiration soil type, and land use data. The GIS based extension tool HEC-GEOHMS and HEC-GEORAS were mainly used for preparation of inputs for HEC-HMS.

The model was calibrated for two years flow data and verification of the calibrated parameters for one year's flow data. For this study, the result shows that Nash efficiency and degree of determination ( $\mathrm{R}$ - squared value) is more reliable. The peak flow and time to peak at the outlet using trapezoidal channel section is nearly matched to the observed peak flow and time to peak for calibration and verification period. However the average annual flow and total annual volume at the outlet is slightly deviated from observed mean flow and annual volume respectively.

Following are the specific conclusion from the analysis.

- The model provides the best result as a function of peak flow and time to peak.

- Hydrologic modal parameters can be derived from historic stream flow, precipitation and GIS database.

- The reasonable result was obtained for semi distributed model with efficiency from nearly $88.51 \%$ for calibration period and $87.12 \%$ for verification period respectively.

- Trapezoidal section can be used for simulation to determination of annual runoff. 


\subsection{Recommendations}

From the study result, suitable channel section can be used for similar channel routing model. To develop capability of the model, following significant concepts are needed for further similar studies.

- Digital elevation model plays vital role to enhance the capability of model. It is recommended to use high resolution digital spatial database for real replication of topography for the better performance of the model.

- Channel cross sections are derived using HEC-GeoRAS extension of GIS. It should be checked by field surveys to get better result.

- It is recommended to consider contribution of snow for better result.

- To achieve better result, calibration and verification of the model should be carried out in individual sub-basin for similar studies.

\section{References}

[1] Beven and Kirkby (1979) "Assessing the effect of spatial pattern of precipitation in modeling stream flow hydrographs.' Water Resour. Bull., 823-829.

[2] Bhattrai J. R. (2008) Routing of the flood waves from Sub watershed of Koshi Basin at chatara, M.Sc. thesis water resource engineering IOE pulchowk campus.

[3] Bhattarai R. (2007) application of Distributed hydrologic soil vegetation model (DHSVM) in plain region of Nepal M.Sc. thesis water resource engineering IOE pulchowk campus.

[4] Gautam NP (2009) Effect of channel geometry on routing in the case of Gandaki river basin, M.Sc. thesis water resource engineering IOE pulchowk campus.

[5] Choudhury p, Shrivastava rk and Narulkar sm (2002) Flood routing in river networks using equivalent Muskingum inflow. J. Hydrol. Eng. 7 (6) 413-419.

[6] Chow, V.T.et, al (1988), Open channel flow. McGraw-Hill, Singapore.

[7] Cunge ja (1969) On the subject of a flood propagation computational method (Muskingum method). J. Hydraul. Resour. 7 (-) 205-230.

[8] Dianas et al, hydrologic and hydraulic analysis of less studies watersheds, faculty of civil engineering , Croatia.

[9] Di Luzio, M., R. Srinivasan, and J. G. Arnold. (2001), Soil and Water Assessment Tool ArcView Interface Manual. Version 2000.

[10] Dugger, A.L. (1997), Linking GIS with the Hydrologic Modeling System: An Investigation of the Midwest Flood of 1993, M. Sc. Thesis, University of Texas at Austin, USA.

[11] Esri (1996), Introducing ArcView; the Geographic Information System for Everyone, Environmental Systems Research Institute (ESRI) Inc., Redlands, California.

[12] Fleming, M., (2002), Continuous hydrologic modeling with HMS: parameter estimation and model calibration and validation. Msc Thesis, Tennessee Technological University.

[13] Gautam, D.K. Hydrological modeling, Department of hydrology and Metrology, Nepal.

[14] Green, W.H. and Ampt, G.A. (1911), Studies on soil physics, part I, the flow of air and water through soils. Journal of Agricultural Sciences 4(1): 1-24. 
[15] HEC (2001), Hydrologic Modeling System HEC-HMS. Version 2.1 Tech. Ref. Manual, USACE, Hydrologic Engineering Center, Davis, California, USA.

[16] Hydrologic Engineering Centre (HEC, 1979), Introduction and application of kinematic wave routing techniques using HEC-1, Training Document 10. Hydrologic Engineering Center, Davis, CA.

[17] J. Blackburn A.F.E. HicksB, Professor, Department of Civil and Environmental Engineer, University of Alberta, Edmonton, AB, Canad, Combined flood routing and flood forcasting.

[18] Jacob B.S. (1995), Hill Irrigation Engineering with special emphasis on planning, designing and implementation of farmer hill systems, Institute of Engineering, Pulchowk, Nepal.

[19] Lawler ea (1964) Flood routing. In: US Army Corps of Engineers (ed.) Handbook of Applied Hydrology, Section 25-II River Division. US Army Corps of Engineers, Ohio, USA. 35-58.

[20] Lu Mingfeng Zhao Qiang,1980, semi-distributed daily runoff process modeling with the aid of gis: a case study of yanqi catchment in beijing, northern china, Cold and Arid Regions Environment and Engineering Research Institute, Chinese Academy of Sciences, Lanzhou, 730000, the People's Republic of China.

[21] Maidment, David R. (2000), Floodplain Visualization Using HEC-GeoRAS, Center for Research in Water Resources, University of Texas, Austin, USA.

[22] Mamillapalli, S., Srinivasan, R., Arnold, J.G., Engel, B.A., (1996), Effect of spatial variability on basin scale modeling. Proceedings, Third International Conference/Workshop on Integrating GIS and Environmental Modeling, Santa Fe,New Mexico, January 21-26, 1996.

[23] Matthew T. Swenssor, (2003), Refinements on a GIS-based spatially distributed rainfall-runoff model for the small watershed (School of Engineering, University of Pittsburgh, 2003).

[24] Nerc (1975) Flood-Routing Studies. Report No V-III. Natural Environment Research Council, London, UK.

[25] Nguyen Hong Quan(2006), Rainfall-Runoff Modeling in the Ungauged Can Le Catchment, Saigon River Basin, MSc Thesis International Institute For Geo-Information Science And Earth Observation, Enschede, Netherland.

[26] Olivera F, (2001), Extracting Hydrological Information from Spatial Data for HMS modeling, Journal of Hydrologic Engineering, American Society of Civil Engineers, 524-530.

[27] Rijal S.P. (2001), Optimization of Catchment Routing Parameters of Jhikhu Catchment in Nepal, M. Sc. Thesis, Water Resources Engineering Program, Institute of Engineering, Pulchowk, 2001.

[28] Sagar Aryal (2007) application of Distributed hydrologic model (BTOPMC) in Narayani Basin M.Sc. thesis water resource engineering IOE pulchowk campus.

[29] Singh, V.P. and Woolhiser, D.A. (2002), Mathematical modeling of Watershed hydrology, Journal of Hydrologic Engineering, 7(4): 270 -292.

[30] Subramanya K.(1994), Engineering hydrology, second edition, Tata McGraw Hill Publications.

[31] Suwal,G.R.(2006), Assessment of hydropower potential using GIS: A case study of Madi River Basin, M.Sc.Thesis, Water Resources Engineering Program, Institute of Engineering,Pulchowk.

[32] Thapa D. R. (2008), Assessment of hydropower potential a case study of Kaligandaki Basin.

[33] Thapa (2003), Application of Computer based tool in flood plain analysis incorporating hydrological impact of Global Climate change: A case study of Bagmati basin in terai, M.Sc thesis, Institute of Engineering.

[34] Wilson em (1990) Engineering Hydrology. MacMillan, Hong Kong, China. 